\title{
Advancing Gender Equality through European Employment Policy: The Impact of the UK's EU Membership and the Risks of Brexit
}

\author{
Colette Fagan* and Jill Rubery** \\ *The University of Manchester, UK \\ E-mail: colette.fagan@manchester.ac.uk \\ ** The University of Manchester, UK \\ E-mail: jill.rubery@manchester.ac.uk
}

This article examines the development of the EU's gender equality framework of 'hard' and 'soft' law, including the incomplete gender mainstreaming of the European Employment Strategy. It highlights contradictions, rooted in political tensions between the social democratic principles which underpin the European Social Model, and the promotion of neo-liberal economic policies. It assesses the UK's role in shaping this European framework, and the framework's impact on the UK's employment policy. It concludes that Brexit will harm the pursuit of gender equality in the UK due to decoupling from the EU's equality framework and policy pathway. An additional risk is greater insularity in UK policy making through reduced exposure to the Open Method of Coordination. Brexit may, however, help progress gender equality in the rest of the $E U$ if the outcome is greater unity focussed on an inclusive employment policy without the UK dragging its heels in favour of deregulated flexibility.

Keywords: Brexit, European Union, employment policy, gender inequalities, gender mainstreaming.

\section{Introduction}

The EU has played a major role in putting gender equality on the policy-making agendas across Europe and in normalising the inclusion of gender equality principles in policy discussions within the framework of the European Employment Strategy (EES) and the Social Inclusion Process (SIP). This article first considers the development of the EU's gender equality framework of 'hard' and 'soft' law and its contribution to comparative benchmarking. The next section focuses on the impact of the EU's gender equality framework of hard and soft law on steering the employment policy trajectory in the UK, drawing on developments in three key policy areas.

Our analysis highlights the contradictions and tensions that have emerged from the incomplete gender mainstreaming of European employment policy and the scope for gender equality objectives to be co-opted and subordinated for particular employment and political objectives (Stratigaki, 2004). This reflects the political struggles in the European arena between the pursuit of the social democratic principles underpinning the 'European Social Model' and the promotion of neo-liberal economic policies (Wickham, 2005). The outcome is an emphasis on, for example, flexible hours policies that are seen as helpful 
for the wider economic agenda while issues such as the gender pay gap are underplayed where remedies might challenge rather than support neoliberal policies (see for example EU, 2003).

Our conclusion is that decoupling from the EU's equality framework due to Brexit will harm the pursuit of gender equality in the UK. The vitality of the EU framework has ebbed and flowed over the forty years of membership but it has largely been ahead of developments in the UK and provided a catalyst to further action. It also roots gender equality in international law that prevents the abolition of rights by governments unfavourable to gender equality, but only if the UK remains an EU member. Brexit may also be occurring as the EU moves onto a new policy pathway to develop a European pillar of social rights aimed at creating more inclusive labour markets and reducing precarious work. Another loss may come from reduced exposure to comparative benchmarking and evaluation through the Open Method of Coordination, replaced by a more insular approach to policy design. Brexit may, however, help progress gender equality in the remaining member states if the outcome is greater EU unity focused on an inclusive employment policy without the UK dragging its heels in favour of deregulated flexibility.

\section{The development of the EU's policy mechanisms for advancing gender equality in employment}

Gender equality policy is probably the most developed dimension to the European Union's (EU) social dimension (Hyman, 2008) due in part to its inclusion in the original Treaty of Rome. Furthermore, as Walby (2003) claims, the EU has also often led from the front in this arena, ahead of policy development in many member states. There are three elements to the EU's gender equality policy: the gender equality regulatory framework (hard law), the gender mainstreaming of both policy formation (guidelines and policy processes) and funding policies (European social funds), and the sustained cycle of national benchmarking and policy scrutiny through the Open Method of Coordination (OMC).

This body of gender equality measures, summarised in Table 1, has emerged through multiple mechanisms promoted by policymakers with often divergent interests and objectives (Lewis, 2006). Specific gender equality objectives have shaped many of the measures but equally important are the pressures for 'adaptive' policies to adjust to the changing labour market and household behaviour of men and women and for 'instrumental' policies that promote some aspects of gender equality primarily for its impact on other policy domains (Stratigaki, 2004; Jenson, 2008, 2009; Rubery, 2015). Instrumental policies may lead to potential mutual benefits, for example increasing gender equality in access to employment to secure the overall goal of raising Europe's employment rate. This tension between instrumental and equality objectives takes on particular importance in a context where the EU's dominant policy agenda is neoliberal in form, with the consequence that gender equality objectives have been used to legitimate policy objectives with questionable benefits for progressing gender equality, such as certain forms of flexible labour markets.

The development of the legal framework

The EU's gender equality policy has its roots in the inclusion of article 119 on equal pay in the 1957 Treaty of Rome article, an inclusion motivated not by social justice 
Table 1. The EU's gender equality framework of hard law, soft law and financial incentives

\section{Hard Law (Directives and ECJ case law)}

Mid-1970s - 1980s: Equal pay, sex discrimination, and equal treatment in social security.

- Directive on equal pay for men and women, (75/117/EEC)

- Directive on equal treatment of men and women in employment 976/207/EEC amended by Directive 2002/73/EC and then Recast Directive 2006/54/EC)

- Directives on equal treatment of men and women in statutory schemes of social security (79/7/EEC) and occupational social security schemes (86/378/EEC, amended by Directive 96/97/EC and then Recast Directive 2006/54/EC)

- Directive on equal treatment of men and women engaged in a self-employed capacity, including in agriculture (86/613/EEC repealed and amended by Directive 2010/41/EU) 1990s: Family leave, equal treatment for part-time workers, and other labour standards.

- Maternity leave (Pregnant Workers' Directive 92/85/EEC)

- Parental Leave Directive (96/34/ EEC, repealed by Directive 2010/18/EU)

- Equal treatment for part-time workers (Part-time Work Directive 97/81/EC)

- Fixed-Term Work Directive (99/70/EC)

- Working Time Directive (2003/88/EC)

2000s: Equal treatment for consumer rights.

- 2004/2012 the Directive on equal treatment of men and women in the access to, and the supply of, goods and service (2004/113/EC)

2012 Proposed directive: gender quotas for corporate boards (EC, 2012 -COM[2012]614)

Soft Law (EES \& OMC, targets, guidelines and good practice policy sharing)

The European Employment Strategy (EES) and Open Method of Coordination (OMC)

- 1997 EES launched: equal opportunity one of four pillars

- 1998 Gender mainstreaming introduced into EES

Country-specific recommendations introduced into the EC's OMC assessment of National Action Plans

- 1999: OMC reforms National Action Plan (NAP) process to introduce country specific recommendations to member states to meet EES objectives (prepared by EC and endorsed by Council of Ministers)

Target setting introduced

- 2000 Lisbon strategy: female employment rate target of $60 \%$ by 2010

- 2002 Barcelona: pre-school childcare targets.

Diminishing emphasis on gender equality objectives in EES

- 2002 The four pillars are replaced by 10 guidelines - gender equality retained as one guideline

- 2003 Equal opportunities disappears as separate topic as EES integrated with Broad Economic Guidelines

European Pact for equality between women and men (2011-2020) (Council of the EU,2011) annexed to Council conclusions (7166/11)

- Reaffirms the EU's commitment to closing gender gaps in employment, education and social protection; promoting better work-life balance for women and men; and combatting all forms of violence against women

- The Pact encourages member states to promote gender equality policies, especially with regards to the employment policy guidelines 
Table 1. Continued

Soft Law (EES \& OMC, targets, guidelines and good practice policy sharing)

\section{Other soft law tools including:}

- Good practice policy exchange mechanisms (e.g. see EC, 2017c)

- Guidelines and codes of practice: Recommendation on strengthening the principle of equal pay between women and men through pay transparency (EC, 2014), Communication on work life balance (Commission of the European Communities, 2008), Sexual harassment (Council of the EU, 2004), Reversing the burden of proof (Council of the EU, 1997; EC, 2015c).

\section{Financial tools}

1990s- European social funds: required gender equality and gender mainstreaming in performance criteria

2000s- European research and development funding (Framework programmes and European Research Council): gender mainstreaming introduced as an evaluation criterion for research project and team composition; developed further in the current Horizon 2020 programme

but by France's concerns, having already introduced an equal pay act, over unfair trade (Pillinger, 1992). Nearly twenty years passed before this article was activated through two fundamental directives on equal pay and on equal treatment passed in the mid-1970s that have provided the cornerstone of subsequent EU gender equality policy. In retrospect the timing was opportune as their introduction preceded the 1979 UK election of Margaret Thatcher's Conservative government and its repeated use of the national veto to block EU legislation. Their impact was strengthened by European case law that introduced the principle of indirect as well as direct discrimination, opening the way for a wider conception of equality measures linked, for example, to part-time work; this is in contrast to the United States where part-timers can be legally treated differently to full-timers, even though most are women, for example by excluding them from health care insurance (Tomlinson, 2007).

However, the legislative route to gender equality has been constrained by political factors both national and European (see Hantrais in this issue). In the 1980s and 1990s the UK provided the main visible obstacle, and new legislation - for example the maternity directive, the paternity leave directive and part-time workers' directive - were only passed by being taken under mechanisms that permitted qualified majority voting or through the social chapter of the Maastricht treaty, to which the UK had an opt out. Some directives were weakened before passing, in unsuccessful attempts to get the UK to accept the proposals (for example, maternity leave). These gender equality measures were complemented by a couple of directives passed for reasons other than gender equality that had notable equality spin-off benefits, especially in an under-regulated economy such as the UK. These included protections of employment conditions for outsourced workers under the Acquired Rights Directive 77/187/EC (amended 2001 and renamed the Transfer of undertakings directive 2001/23/EC) which put some limits to the UK government's programme to outsource many women's jobs from the public to the private 
sector, and new rights for paid holidays for part-time workers as well as full-time under the 1993 Working Time Directive (2003/88/EC).

Although the election of New Labour led to the rescinding of the social chapter opt out, New Labour and all subsequent governments have continued the practice of opposing further social legislation. Since the 1990s the main gender equality related directives only deal with consumer rights. The UK has insisted on exclusion from the fundamental charter on social rights and has acted with others - including some new member states - to block proposals to strengthen the maternity leave directive (EUOBSERVER, 2015) and to enhance parental leave (EC, 2017a) (see Guerrina and Masselot in this issue). This wider coalition against more legislation makes it unlikely that other current proposed directives on work life balance and corporate board quotas will reach the statue book. However, even a weak prospect of legislation can apparently still have a catalytic effect. The protracted European Parliament debate about a directive to establish gender quotas for corporate boards created an environment in which a number of countries brought forward voluntary measures to pre-empt legislation (Fagan et al., 2012a). Likewise, several member states have introduced compulsory gender pay audits for organisations (for example, new policies in Germany, Austria, the UK and Spain alongside more established policies in, for example, Sweden (Rubery and Kouliadaki, 2016)) in the context of the development of the recent recommendation on pay transparency and gender pay auditing (EU, 2014) which may be a tactic to pre-empt any plans to turn the recommendation into a directive.

Despite the frustrations of recent years where even modest attempts to strengthen legal rights have often been blocked, the European Union's gender equality legal framework still operates as a catalyst for reform for countries applying for EU membership, and later entrants have had to meet a higher threshold of conditions as the framework expands over time. While national gender equality measures prior to membership could match or exceed the EU requirements, most, with the exception of Sweden, did not. The UK only introduced its laws on equal pay and sex discrimination after being offered EU membership and to coincide with the EU's legislation. The southern European countries that sought membership after the fall of dictatorships (Spain, Greece, Portugal) introduced gender equality laws to strengthen their applications. For them, and the new member states joining from 2004 onwards, the EU's gender equality legislation is part of the acquis communitaire which new member states are required to comply with as a condition of membership.

The development of soft law through the adoption of gender mainstreaming in the European Employment Strategy

Alongside the stalled extension of the legal framework for gender equality, two developments triggered a growing role from the mid-1990s onwards for so-called soft law - non-binding measures - as a tool for promoting gender equality. The first was the call for gender mainstreaming by the 1995 UN World congress on women which created a climate in which including gender equality objectives within soft law could be considered an obvious but nevertheless significant development (UN, 1995). The EU was both an active advocate of gender mainstreaming in the UN conference and also an early adopter, committing to 'mobilization of all Community policies for the purpose of promoting gender equality' from 1996 (EU, 1996) and subsequent activities 
to build stakeholder capacity in gender mainstreaming methodologies (e.g. European Commission, 2005).

The second development was the 1997 launch of the European Employment Strategy (EES), which introduced OMC - a soft law form of governance that requires member states to prepare action plans according to common principles and to receive and respond to recommendations in a regular cycle of policy scrutiny and benchmarking (Pollack and Hafner-Burton, 2000; Zeitlin et al., 2005). The EES included equal opportunities as one of four pillars of the policy, and by 1998 a gender mainstreaming requirement was included for all EES policies (Rubery, 2002).

The factors behind this initial strong focus on gender equality included the momentum behind the Beijing conference, reinforced by the EU being joined by two Scandinavian countries with strong gender equality traditions in 1994 (Pollack and Hafner-Burton, 2000), and the fortuitous appointment of a Swedish Director-General for employment and social affairs, the social democratic politician Allan Larsson. For once the UK government played a positive role by supporting the gender mainstreaming of the EES during its 1998 presidency of the European Union (Pollack and Hafner-Burton, 2000).

One of the most important consequences of this gender mainstreaming was that a gender equality focus was included in the evaluation criteria for the European social funds, thereby creating financial incentives to engage in promoting gender equality for those countries in receipt of these often significant resources. The redrafting of regulations at the end of the 1990s had the intention of ensuring that ' $[T]$ he gender dimension would in effect permeate the whole process, from the planning through to evaluation' (EU, 1999: 7). This influence on the social funds has been maintained, even during times when gender equality all but disappeared from the EES - for example, in Greece at the height of the austerity crisis (Karamessini, 2014). Likewise, gender mainstreaming is now embedded in the assessment criteria for the competitive allocation of the EU research framework funding, in the design of research programmes and in the associated programme to promote gender balance in science (EC, 2015a, 2015b). Furthermore soft law mechanisms for gender equality have become part of the negotiation of EU membership. For example, in the accession process Bulgaria and Romania were encouraged and expected to use voluntary measures to promote women's representation in politics in addition to implementing EU hard law (Chiva, 2009).

The late 1990s proved to be the high point for gender equality and gender mainstreaming in the EES, with the emphasis on gender equality steadily downgraded from 2002 onwards as the EES became integrated with the broad economic guidelines (Table 1) and as the social democratic ethos of the EES was increasingly subordinated to neo-liberal economic policy (Rubery et al., 2003, 2004; Fagan et al., 2005, 2006a). There were still some positive developments under the 2000-2010 Lisbon strategy, notably the establishment of a female employment rate and pre-school childcare targets but this gender visibility literally disappeared during the financial crisis in the first draft of the Europe2020 strategy to succeed the Lisbon strategy. Gender equality only reappeared and in a weak form after member states queried its omission (Smith and Villa, 2010). Gender mainstreaming had already waned before the financial crisis but was completely absent in the austerity programmes that dominated over these soft law initiatives in the most severely affected member states. Only under the new Juncker commission has there been any revival of the social dimension with the proposed new pillar of social rights (EC, 2016c; EC, 2017b) which both include commitments to specific gender measures 
such as gender equality, work life balance and childcare, but also to some pillars of employment policy that are vital for gender equality such as minimum wages at decent levels ${ }^{1}$ (see Plomien in this issue). However, this pillar is being developed in parallel with the continued pursuit of more deregulated labour markets through the employment strategy, with country-specific recommendations advocating moderating minimum wage claims without reference to equality issues or decent work standards (ETUI, 2017).

Progress through gender mainstreaming had to be assessed in relation to employment policy analysis before the EES was launched. The Delors white paper (EU, 1993) on employment policy that led to the EES presented as a puzzle the fact that most of those entering employment over recent years had come from inactivity not unemployment ${ }^{2}$. That most of these entrants were women was not considered.

The most enduring legacies of the gender mainstreaming of the EES are twofold. First increasing women's integration into employment has become a standard employment policy objective, recognised to bring economic benefits, particularly with an ageing population. This is indicated by the use of the employment rate to monitor progress instead of the unemployment rate and by setting a separate target for women's employment to 2010. This approach contrasts with the immediate post-war period of so-called full employment where high inactivity among women was seen as the norm. Second, the widening scope of employment policy to include care services also marked a major change from regarding labour markets as disconnected from the domestic and care sphere, and also promoted a drive towards more public provision of childcare across the EU member states.

That said, many policy areas of the EES remain either gender blind or provide examples where the gender equality goal has been instrumentally subordinated to other agendas. A gender blind approach persists in relation to wage setting: most recommendations to member states link wages to productivity or advocate moderate minimum wage levels (ETUI, 2017), with no analysis of contradictions with policies to reduce the gender pay gap. Likewise, policy debates and country-specific recommendations on skill shortages rarely include a systematic consideration of gender segregation. Thus gender mainstreaming has remained rather superficial and is often totally ignored at both member state and EU level (Rubery, 2002; Rubery et al., 2003, 2004; Fagan et al., 2005, 2006a; Plantenga et al., 2007; Smith and Villa, 2010).

The risk that gender equality objectives may be subverted into supporting policies harmful to gender equality in the longer term is particularly evident in the area of work life balance. The gender equality goal of more equal sharing of care work became a means of legitimising the promotion of flexible labour markets (Stratigaki, 2004). A stereotyped and normative notion of women's preferred arrangements for caring for children and other family members was used to recommend more part-time work opportunities to further gender equality even in countries where women were already well integrated in full-time work and had shown little preference for part-time hours. The instrumental nature of some gender equality policies became more evident after the financial crisis: for example, the promotion of women's employment up to that juncture had had a generally positive impact on women's opportunities and was associated with increasing care services. Austerity brought to an end the prospect of convergence around the high level of care services found in Scandinavia but the pressure on women to engage in wage work remains even when support for that work is reduced (Lewis et al., 2016). In part this reflects the focus on changing women's behaviour while men's behaviour remains outside the remit of the 
EES, despite the increased recognition in other parts of the European Commission that men's behaviour and opportunities for care work need to be part of an effective gender equality strategy (Fagan and Norman, 2013). Likewise policies directed at lone parents were restricted to a focus on their employment integration and 'making work pay' in both the EES and the subsequent launch of the Social Inclusion Process (Fagan et al., 2006a), without a broader consideration of the limits of a gender equality policy model premised upon a dual-earner couple or indeed of the responsibilities of non-resident fathers.

\section{Gender mainstreaming of evidence and policy design and evaluation}

The adoption of the gender mainstreaming principle has had a spill-over benefit on the evidence base for gender equality policies as gender is expected to be taken into account in the research and evidence base for all European policy areas. One example outside the employment area is the collection of data on gender inequality in research since 1998, which has resulted in more continuous commitment towards monitoring of data by gender equality (see Table 2). In employment and social policy the consequence has also been a more systematic collection and analysis of gender disaggregated data which informs the policy scrutiny and institutional learning of the OMC as well as debates in wider policy forums. Key examples related to gender analysis of employment and social conditions are summarised in Table 2.

The main gender-specific indicators used to assess the Lisbon strategy included the female employment rate, the gender pay gap and childcare targets. At certain times, monitoring of these data was reinforced by soft policy commitments to close specific gender employment or pay gaps. However, even at the highpoint of gender monitoring and analysis there were many deficiencies. For example, employment rates were monitored by headcount, not by full-time equivalents, thereby overstating achieved gender equality, particularly in countries like the UK and the Netherlands with a high share of women working part-time. Although the EGGSIE employment and gender equality expert group made suggestions for improved indicators to the employment committee, few were adopted or maintained (Rubery et al., 2001). Such consultation has not been repeated and the scorecard for Europe2020 contains no gender disaggregated data or targets.

Overall the momentum in the European Commission behind regular gender analysis of core employment trends has declined, though some specific and detailed analyses still appear within core publications from time to time (see ch.3 in EU, 2013).

However, the availability of gender disaggregated harmonised European datasets ${ }^{3}$ has enabled and fostered an industry of comparative European research that has contributed to identification of the specificities of each country's gender model. This has been undertaken by European Commission funded networks of expert advisors ${ }^{4}$ - for example, on legal issues, childcare and employment and social inclusion - by international comparative research projects funded by the research framework programmes and by EU-funded policy observatories and good practice policy exchange networks ${ }^{5}$.

These international comparisons provide an evidence base to counter the view that the prevailing gender model is a 'common sense' adaptation to biological gender differences. The quite different models adopted by close neighbours have revealed that, for example, the particular role and organisation of part-time work in the UK is not found everywhere. The UK has been found (EU, 2002) to be the only country to impose extra pay penalties on part-time workers and to have many fewer part-time work opportunities 
Table 2 European data resources for gender equality benchmarking and monitoring

\section{Policy area: Employment and social conditions}

\section{Benchmarking statistics collected:}

Under the Lisbon strategy the core benchmarking indicators included the female employment rate, childcare targets, and the gender pay gap but under Europe2020 the scoreboard includes no gender disaggregated or related indictors

http://ec.europa.eu/eurostat/web/europe-2020-indicators/europe-2020-strategy/headlineindicators-scoreboard

Core Eurostat data on employment and social conditions is largely gender disaggregated.

Additional gender equality and national comparative benchmarking data is available from the $\mathrm{EU}$ and its agencies. In particular

- The EC's Justice, Consumers and Gender Equality group provide an annual review on the EU's progress in implementing the strategic engagement plan (2016-19) for gender equality (EC, 2015d [EC Gender Data Monitoring Report])

- Comparative gender-disaggregated data on working conditions, job quality, and living conditions are collected by Eurofound's time series surveys

https://www.eurofound.europa.eu/surveys/european-working-conditions-surveys

Policy area: Women's under-representation in political and economic decision making

\section{Benchmarking statistics collected:}

The EC's European Institute for Gender Equality (EIGE) maintains a data base on women in decision-making covering 35 European countries

http://eige.europa.eu/gender-statistics/dgs/browse/wmidm

The domains covered include: politics; public administration; judiciary; business and finance; social partners and NGOs; environment and climate change; and media.

\section{Policy area: Women's under-representation in research and innovation}

\section{Benchmarking statistics collected:}

Since 2003 the EC has collected SHE statistics on women in research and innovation every three years. Horizon 2020, the current research framework programme, is being monitored and evaluated for

- the percentage representation of women in Horizon 2020 projects as (i) participants (ii) project coordinators (iii) members of advisory groups, expert groups, evaluation groups and panels;

- projects with a gender dimension in the project design (EC, 2015a; EC, 2016a).

in higher level jobs than other high part-time countries such as the Netherlands (Fagan et al., 1995). International comparisons also reveal the UK to have very high childcare costs, long full-time hours, and wide wage inequalities, providing an important evidence base to counter government claims that the UK's flexible labour market is beneficial for gender equality.

The impact of international comparison and benchmarking is reinforced through country-specific recommendations scrutiny and opportunities to share 'good practice' through the observatories, mutual learning events and peer review processes of the OMC 
of the EES. Here the main gender focus is around activation (for example, events on making work pay for mothers in 2015 and pathways to work for single parents in 2010) but there are also peer review events in areas such as childcare organised by the Gender Equality Unit. This unit is now situated in DG Justice instead of DG Employment, which may reduce its internal influence in the Commission concerning gender mainstreaming employment policy. Certainly this move, coupled with the establishment of a separate gender institute (EIGE) has led to a renewed focus on gender equality rather than mainstreaming; as exemplified in the EIGE's database on women in decision-making which has supported the push for more female representation on corporate boards.

\section{The impact of EU membership on measures to promote gender equality in the UK's employment and social inclusion policy}

The UK's gender equality legislation and policy has been shaped and often driven by the EU gender equality framework discussed above. The framework's content has been shaped by policy 'upload' and transfer from countries with more developed gender equality policies, notably the Nordic countries, and the progressive gender equality agendas of pan-European organisations such as the European Trade Union Confederation and the European Women's Lobby, through the social democratic practice of tripartite consultation which underpins the EU's governance model, including the OMC. The 'download' of this framework into the national setting has added political weight to the agendas of UK-based campaigning groups.

The EU's proposed hard law measures were the catalyst for the introduction of the 1970s equalities legislation in the UK (Table 3), backing national campaigns by feminists, some unions and other civic groups . Despite the UK's political efforts, discussed above, as a member state to veto, delay or dilute further Directives and ECJ case law, the evolution of the EU's gender equality legal framework (Table 1) continued to be an important driver for UK equality legislation from the 1970s onwards (Table 3).

The EU's 'soft law' gender equality measures have also been influential, particularly through the integration of principles of gender equality and gender mainstreaming into the initial phases of the EES (Table 1) which opportunely coincided with the change to a Labour government in 1997 after eighteen years of Conservative rule. This initiated a thirteen-year period of a somewhat more co-operative approach towards the European Union's employment and social policy agenda than its Conservative predecessors or the subsequent Conservative-Liberal Coalition (2010-15) and the 2015 Conservative government that led to Brexit.

The reflection of the uneven gender mainstreaming of European employment policy in UK employment policy is evident in two important examples. First, policies to redress skills shortages in both EU and UK arenas lack a gender analysis. In the UK this underdevelopment can be traced from the government's 2004 Leith Review through to the current Industrial strategy, with the only serious consideration of gender issues confined to the 2006 separate government-sponsored 'Women and Work' Commission. Instead of the EU challenging this approach, it has issued recommendations to the UK to develop the skills base of the workforce in every round of OMC assessment since 1999 without once including a gender dimension. Second, the European Commission failed to follow its own policy of promoting gender impact assessment and gender budgeting analysis (European Union, 1996) by not assessing the gender effects of member states' 
Table 3 UK gender equality legislation and soft law mechanisms

\begin{tabular}{|c|c|}
\hline \multicolumn{2}{|r|}{ Equality legislation } \\
\hline 2010 & $\begin{array}{l}\text { Equality Act - extends and replaces prior equality legislation. Includes } \\
\text { removal of the prior exemption for equal treatment in financial services } \\
\text { from December } 2012 \text { onwards }\end{array}$ \\
\hline 2007 & $\begin{array}{l}\text { Gender Equality Duty placed on all public authorities. Replaced by the Public } \\
\text { Sector Equality Duty which covers gender, race and disability equality } \\
\text { duties (April 2011) }\end{array}$ \\
\hline 2004 & $\begin{array}{l}\text { Equal treatment in access to, and supply of, goods and services via EC } \\
\text { Council Directive (2004/113/EC) }\end{array}$ \\
\hline 2002 & $\begin{array}{l}\text { Fixed-term contracts via the Agency Workers Regulations } 2010 \text { (S1 2010/93); } \\
\text { Fixed-term Employees (Prevention of Less Favourable Treatment) } \\
\text { Regulations (S1 2002/2034) }\end{array}$ \\
\hline 2000 & The Part-time Workers (Prevention of Less Favourable Treatment) Regulations \\
\hline 1984 & Equal value amendment to Equal Pay Act \\
\hline 1975 & Statutory Maternity Leave via the 1975 Employment Protection Act \\
\hline 1975 & Sex Discrimination Act \\
\hline 1970 & Equal Pay Act \\
\hline
\end{tabular}

\section{Gender Pay Gap}

2017 Mandatory Gender Pay Gap reporting (large organisations)

1998 Statutory National Minimum Wage introduced

1981 Transfer of Undertakings (Protection of Employment) Regulation was extended to cover the public sector following an ECJ ruling (March 1997), which reduced incentives to outsource women's work

\section{Working-time/work-family reconciliation}

2015 Shared Parental Leave introduced under the 2014 Children and Families Act. This replaced Additional Paternity Leave, introduced in 2011 via new regulations implemented in 2010 in the 2006 Work and Families Act. Unpaid parental leave of 13 weeks introduced in 1999, extended to 18 weeks in 2013

2003 Right to Request Reduced or Flexible Working Hours - for employees with a child aged under 6 years (or 18 years if disabled); coverage extended to carers of disabled adults (2007), all children aged under 16 years (2008), all employees (2014)

$2000 \quad$ Maternity leave and paternity leave

and Maternity leave extended from 14 to 18 weeks in 2000 (Employment Rights

2003 Act 1999), extended to one year in 2003: 26 weeks of ordinary (paid) leave and 26 weeks of additional (unpaid) leave (Employment Act 2002) leave.

Two weeks paid paternity leave introduced in 2003 (Employment Act 2002).

1998 Working-Time Directive: statutory entitlement to paid annual leave had major impact on part-time workers; but the UK opt out of the 48 hour limit on weekly working hours meant the Directive had limited impact on the long full-time working hours practiced in many UK organisations 
Table 3 Continued

\section{Childcare services}

1998 National Childcare Strategy: introduced an entitlement for all 4 year olds in England to a free part-time place in pre-school education for 12.5 hours per week for 33 weeks per year. The free childcare entitlement was rolled out to 3 years olds in 2004 and increased to 38 weeks per year (school term-time). In 2010, the entitlement was extended to 15 hours a week during term-time. In 2013, the childcare entitlement was extended to $20 \%$ of two year olds from the most disadvantaged areas in England; and to $40 \%$ of the most disadvantaged two year olds in 2014.

The 2016 Childcare Act extends free childcare places to working parents for 30 hours a week from 2017.

Sure Start was launched in 1999 under the NCS to deliver services and support to young children and their families through children's centres. The focus is on the period from pregnancy through to school-age, but also provides services for children up to 14 years of age (16 years for those with disabilities and special education needs).

\section{Target setting for gender balance on corporate boards/in high level positions}

2016 Women in Finance Charter launched - designed to improve gender diversity in senior positions in the financial sector

2011 In 2011, Lord Davies set a target of 25\% female representation on FTSE 100

and boards by 2015. This was exceeded (at 26.1\%). Progress still to be made in

2016 the FTSE250 where women accounted for $20.4 \%$ of board positions in 2016.

In 2016, the Hampton Alexander review set a target of 33\% female representation in the FTSE100 by 2020. It also recommends the FTSE350 companies disclose the gender balance of their executive committees.

2016 Women and Equalities Committee enquiry into women's representation in the lower house of UK Parliament launched.

The report noted only $30 \%$ of sitting Members of Parliament are women. It recommends a target of $45 \%$ female representation in Parliament and local government by 2030 and a statutory minimum proportion of female parliamentary candidates in general elections for each political party.

2015 Women's Business Council two year progress report included several recommendations to support women's workforce participation in business including broadening girls' career choices by creating a greater partnership between schools, career development professionals, business and parents; encouraging flexible working and support for working parents to help mothers returning to work after having children; and providing more support for women who want to set up their own business (see Women's Business Council (2015): Maximising women's contribution to future economic growth: Executive Summary, http://womensbusinesscouncil.dcms.gov.uk/executive-summary/)

austerity programmes (Karamessini and Rubery, 2014). This implicitly sanctioned the UK's Coalition government's successful legal block on the request from the Fawcett Society for a judicial review to provide a gender impact assessment of the austerity cuts to welfare. 
This lack of an EU steer to drive gender equality in some important policy areas has, however, coexisted with more positive influences on other policy developments, including work-family reconciliation, the gender pay gap and target setting for gender balance on corporate boards.

Work family reconciliation measures

Under its manifesto the Labour government (Labour Party, 1996) committed to accepting the EU's social chapter and to introducing childcare and other reforms to enable families to 'better balance' care and employment. The EES added pressure to deliver on these promises through the annual OMC cycle which scrutinised member states' policy plans and progress against targets for expanding female employment and childcare, and asked for a 'comply or explain' accountability on their published assessment, albeit without hard sanctions (Table 1). Every year between 1999 and 2017 the UK received a recommendation to improve childcare as one of an average five or six recommendations concerning employment.

Three presumptions about gender and family responsibilities are woven through the work-family reconciliation measures which have been introduced in the UK since 1997. Firstly, the primary focus is on making it easier for women to combine employment with childraising; attention to men's contribution to care and care for adults came later and in a more limited way. Secondly, the emphasis is on supporting part-time maternal employment. Thirdly, women's employment was explicitly endorsed as a means to raise living standards and reduce child poverty in low-income families, with a particular emphasis on moving lone parents, mainly lone mothers, into employment.

The 1998 National Childcare Strategy triggered a roll-out of publicly-funded parttime pre-school education during school term-time (Table 3). Tax breaks were introduced for families that purchased additional childcare hours, with an emphasis on childcare tax credits to help low-income families, and additional assistance for lone parents under the 'New Deal for lone parents' in conjunction with an increased and explicit expectation that lone parents actively engage in job-seeking. The statutory right to a free childcare place has continued to be extended despite some initial cuts under the 2010 Coalition government's austerity package. However, the promise of childcare has not been matched with adequate resources which is causing major problems in implementing the 2017 extended entitlement to thirty hours free childcare for children aged three to four (House of Commons, 2017). Furthermore, the Coalition government cut childcare tax credits significantly as part of its austerity roll-back of public expenditure on welfare, while retaining the tightened job search expectations for mothers in low income lone and dual-parent households.

Improvements have also been made to maternity leave, modest rights to paid paternity leave and parental leave have been introduced, along with a 'right to request' reduced or flexible hours which has been extended to all employees (Table 3). The EU influence is apparent here as well: the introduction of parental leave was triggered by the EU Parental Leave Directive (see Guerrina and Masselot in this issue), while the employee 'right to request' reduced or flexible working hours was a diluted variant of a Dutch law, which had been widely promoted across the EU as a 'best practice' (Fagan et al., 2006b).

Workers also gained rights to statutory paid annual leave through the EU Working Time Directive, but the UK secured an 'opt out' from the forty-eight hour working week 
limit; as Labour, like Conservative governments before it, refused to set a statutory limit on working hours, despite international evidence that long hours are detrimental for workers' health and work-family reconciliation (Golden, 2012; Tucker and Folkard, 2012; Fagan et al., 2012b; Eurofound, 2017). Instead, it left the onus on individual negotiation under the 'right to request' legislation; supplemented by a short-term 'Work Life Balance' campaign to encourage employers to innovate.

From a low starting point in 1997 these reforms have supported significant changes but policy shortfalls remain, exacerbated by austerity-related public expenditure cuts (Lewis et al., 2016; Fagan and Vermeylen, 2016). Problems of childcare supply, quality and affordability persist twenty years after the launch of the childcare strategy, and public providers are struggling to fund the new statutory entitlement (Harding et al., 2017; House of Commons, 2017). Low flat-rate statutory leave payments combined with complex shared parental leave regulations mean that few fathers take their full leave entitlement. Exercising the 'right to request' became more difficult after the 2008 recession and remains so for those in precarious employment (Lewis et al., 2016). In particular, low-income families are acutely hit by a combination of budget cuts to childcare services in lowincome neighbourhoods, cuts to childcare tax credits and welfare payments, deteriorating real wages and more precarious job prospects in the 'gig' economy.

\section{The gender pay gap}

The gender pay gap is probably the area most influenced by European hard law. The UK's 1970 Equal Pay Act was introduced in anticipation of EU law but only covered equal pay for like work. The UK government opposed the inclusion of equal value principles but only succeeded in watering down the rights, not eliminating them. Their opposition continued even after the EU took action against the UK; but the European Court of Justice forced an amendment in 1984 to allow for equal value claims (Pillinger, 1992).

The initial equal pay act had an immediate impact as it led to a widespread revaluation upwards of minimum pay rates for women in what were, at the time, industry-level collective agreements or wages council orders with wide coverage. The equal value amendment catalysed public sector unions to press for single pay spines constructed on gender neutral or gender sensitive job evaluation schemes (Hastings, 2007). While gender neutral job evaluation is positive in principle, it has had some unanticipated consequences (Rubery and Grimshaw, 2015). The agreement on single pay spines in the public sector prompted strategies to reduce costs. The hard won upgrading of social care workers within the local authority grading scheme was responded to by mass outsourcing of social care to private sector agencies that mainly pay the minimum wage. Another unanticipated problem arose over the issue of back pay which, under European law, must be equally generous for equal pay claims as for other back pay claims. In local authorities, trade unions negotiated deals that provided for less than full back pay, due to concerns about the overall size of the claims and to decisions to prioritise supporting men whose pay might be reduced under the new schemes. No-win-no-fee lawyers challenged the legality of the negotiated deals (Deakin et al., 2015) with the outcome that employers in the public sector are very wary of admitting to any undervaluation due to the potential costs of back pay claims. EU law does not allow for phasing-in of a more gender equal pay structure in contrast to the 1990 Ontario Pay Equity Act which allowed employers time to implement changes ${ }^{6}$. 
These problems of litigation, coupled with a general trend away from job evaluation towards more individualised pay, led campaigners and the Equal Opportunities Commission (subsequently the Equality and Human Rights Commission) to suggest a complementary approach, namely gender pay audits to make pay more transparent and to highlight where problems may lie. Governments of different persuasions resisted repeated calls for compulsory gender pay audits from 1997 onwards until the lack of voluntary action led Prime Minister David Cameron, possibly influenced by pressure from the EU to improve transparency through gender pay audits, to make a surprise decision to make gender pay audits compulsory from April 2017 for companies with more than 250 employees under the Equality Act $(2010)^{7}$. While greater transparency at the company level is welcome, his claim that this would eradicate the national gender pay gap was naïve, given that other pay policies in the UK might have opposing effects, such as the freezing and capping of pay in the public sector where most higher educated women work.

\section{Gender diversity on corporate boards}

The UK polity has always been more comfortable with setting voluntary targets for employers than with mandating action, due to a general resistance to regulation. For example, earlier initiatives - such as the Business in the Community's Opportunity 2000 action campaign to increase women's representation in senior management - secured some success against voluntary targets; and subsequently target setting in the public sector equality duty includes a focus on the lack of gender parity in senior decisionmaking positions.

The European policy debate concerning women's under-representation on corporate boards provides a clear example of how the threat of legislation galvinised target-setting action in the UK (Fagan et al., 2012a; Guerrina and Masselot, in this issue). In March 2011 the European Commission launched a voluntary target for gender diversity on corporate boards, with an explicit warning that a quota might be established if self-regulation failed (European Commission, 2011a), followed in April by a consultative paper on corporate governance that included specific consideration of how to ensure gender balance at board level (European Commission, 2011b). In July 2012, the European Parliament adopted a non-binding resolution which endorsed the European Commission's proposal to introduce gender quota legislation if voluntary steps and dialogue with social partners turned out to be insufficient (European Parliament Committee on Women's Rights and Gender Equality, 2011). This directive is stalled (Table 1).

The UK government moved swiftly to stimulate voluntary action by initiating the Davies review (2011), which introduced a target and introduced annual monitoring and soft law 'comply or explain' intervention targeted at corporations, their board chair and shareholders, with a commitment for the minister responsible to write to every FTSE board chair that could not demonstrate progress. By December 2015 the target had been exceeded, more than doubling the 2011 baseline proportion (HamptonAlexander Review, 2016). In 2016 the target was raised, recommendations extended to executive committees and a high profile focus announced: on redressing women's under-representation in senior positions in the finance sector. The government's Women and Equalities committee recommended targets to increase women's representation in political office which were not adopted. 
Despite the progress secured through voluntary targets, gender parity is still quite far away. By 2016 only 29 per cent of MPs and only 27 per cent of FTSE 100 board members were women, most concentrated in non-executive rather than executive director roles. Hence the UK still lags behind a number of EU member states on this indicator (EC, 2016c, 2017d).

\section{Conclusions}

The development of the EU's gender equality framework of 'hard' and 'soft' law has been important for steering the strength and direction of the UK's gender equality architecture; for, far from being a pace setter in this European arena, the UK has usually sought to stall, dilute or divert legal measures. The partial gender mainstreaming of the European Employment Strategy delivered some important gender equality gains though the focus on raising the female employment target, supported by a target to expand childcare. Yet there have been contradictions and set-backs due to the political tension between the social democratic principles which underpin the 'European Social Model' and the ascendency of neo-liberal macroeonomic and labour market policies. Gender equality principles have been invoked opportunistically to endorse 'adaptive' policies, used instrumentally and subordinated to economic objectives, or increasingly ignored once the employment and economic guidelines were integrated.

In this context the EU's gender equality framework has driven some progressive reforms in the UK: for example, in relation to childcare and other work-family reconciliation measures, the gender pay gap and women's under-representation on corporate boards; while failing to drive gender mainstreaming into other policy areas such as skill shortages or welfare reforms.

Gender mainstreaming principles were marginalised in European policy debates following the financial crisis and largely discarded in the UK's design of austerity policies. In the UK women in low-income households have borne the brunt of the welfare cuts, and are the most exposed to increased job insecurity and deteriorating working conditions (Women's Budget Group, 2017). Cuts in public sector employment and pay have also disproportionately hit women due to their greater employment concentration in this sector. Furthermore acute strains on social care and social services have exposed women employed in these services to increased pressures and deteriorating employment conditions, while also increasing the pressures on women who care for elderly or disabled family members.

Our conclusion is that Brexit will harm the pursuit of gender equality in the UK. This is notwithstanding the decline in interests in gender equality within the EU in the immediate financial crisis and austerity period. Progress is not usually linear and happens more in 'fits and starts' to quote President Obama ${ }^{8}$; despite the ebbs and flows of EU policy, the overall impact has been cumulatively positive. Thus the first problem is the decoupling of the UK from the EU just as the next round of positive initiatives may be starting, promised by the development of a European pillar of social rights aimed at creating more inclusive labour markets and reducing precarious work. Secondly, exiting the OMC will mean that the process of regular scrutiny through evaluation and benchmarking, and good practice exchange, will be replaced by a more insular approach to policy design. This will be exacerbated by new obstacles to collaborative learning by researchers and policy makers: the UK will not be included in routine survey data collection by Eurostat and 
other EU agencies, or in EU-funded collaborative research teams and mobility training networks for postdoctoral and early career researchers unless the UK government pays to be included. It will thus become more difficult for UK-based academics to be part of EUcomparative research projects and for UK-based public servants and other policy makers to gain international experience through career spells in the European Commission and other European policy shaping organisations.

Brexit may, however, help progress gender equality in the remaining member states if the outcome is greater EU unity focussed on an inclusive employment policy without the UK dragging its heels in favour of deregulated flexibility resting on a model of gender relations premised on women's part-time employment and primary responsibility for family care.

\section{Notes}

1 https://ec.europa.eu/commission/priorities/deeper-and-fairer-economic-and-monetary-union/ european-pillar-social-rights_en

2 A small academic expert group was set up to provide a gender perspective on the white paper (EU, 1995).

3 The Eurostat ELFS and SILC datasets and the Eurofound - European Working Conditions Survey, European Company survey in particular.

4 http://ec.europa.eu/justice/gender-equality/tools/experts/index_en.htm

5 For example Eurofound's industrial relations observatory, European Institute for Gender Equality EIGE

6 For details see http://www.payequity.gov.on.ca/en/tools/Pages/guide_to_act5.aspx.

7 http://www.acas.org.uk/index.aspx?articleid $=5768$

8 'The trajectory of progress always happens in fits and starts,' http://www.latimes.com/nation/ la-na-obama-maron-podcast-20150622-story.html.

\section{References}

Chiva, C. (2009) 'The limits of Europeanisation: EU accession and gender equality in Bulgaria and Romania', Perspectives on European Politics and Society, 10, 2, 195-209.

Commission of the European Communities (2008) Communication from the Commission to the European Parliament, the Council, the European Economic and Social Committee and the Committee of the Regions: A Better Work-Life Balance: Stronger Support for Reconciling Professional, Private and Family Life, $\operatorname{COM(2008)} 635$ final, Brussels: http://eur-lex.europa. eu/LexUriServ/LexUriServ.do?uri=COM:2008:0635:FIN:en:PDF [accessed 26.07.2017].

Council of the European Union (1997) Council Directive 97/80/EC of 15 December 1997 on the Burden of Proof in Cases of Discrimination Based on Sex, https://publications.europa.eu/ en/publication-detail/-/publication/a2ee5fdf-e361-4cd6-a6db-f733f2c447de/language-en [accessed 28.09.2017].

Council of the European Union (2004) Review of the Implementation by the Member States and the EU Institutions of the Beijing Platform for Action - Draft Council Conclusions on Sexual Harassment at the Workplace, 15202/04, Brussels, 25 November 2004, http://register. consilium.europa.eu/doc/srv?l=EN\&f=ST\%2015202\%202004\%20INIT [accessed 01.09.2017].

Council of the European Union (2011) New European Pact for Equality Between Women and Men for the Period 2011 - 2020, 7349/11, Brussels, 7 March 2011, http://eur-lex.europa.eu/legalcontent/EN/TXT/?uri=CELEX\%3A52011XG0525\%2801\%29 [accessed 01.09.2017].

Davies, E. (2011) 'Women on boards', Department for Business, Innovation and Skills, https:// www.gov.uk/government/news/women-on-boards [accessed 01.09.2017]. 
Deakin, S., Butlin, S., McLaughlin, C. and Polanska, A. (2015) 'Are litigation and collective bargaining complements or substitutes for achieving gender equality? A study of the British Equal Pay Act', Cambridge Journal of Economics, 39, 2, 381-403.

ETUI (2017) Benchmarking Working Europe 2017, Brussels: ETUI.

Eurofound (no date) European Working Conditions Surveys, https://www.eurofound.europa.eu/surveys/ european-working-conditions-surveys [accessed 25.07.2017].

Eurofound (2017) Working-Time Developments in the Twenty-First Century: Work Duration and its Regulation in the EU, Publications Office of the European Union, Luxembourg.

European Commission (EC) (2005) EQUAL Guide on Gender Mainstreaming, Directorate-General for Employment, Social Affairs and Equal Opportunities Unit B4, Luxembourg: Office for Official Publications of the European Communities, http://ec.europa.eu/employment_social/equal_ consolidated/data/document/gendermain_en.pdf [accessed 01.09.2017].

European Commission (EC) (2011a) 'EU Justice Commissioner Reding challenges business leaders to increase women's presence on corporate boards with "Women on the Board Pledge for Europe"', Brussels, 1 March 2011, MEMO/11/124, http://europa.eu/rapid/press-release_MEMO-11-124_en.htm [accessed 28.09.2017].

European Commission (EC) (2011b) Green Paper: The EU Corporate Governance Framework, Brussels, 5.4.2011, $\operatorname{COM}(2011) 164$ final: http://ec.europa.eu/internal_market/company/docs/ modern/com2011-164_en.pdf [accessed 28.09.2017].

European Commission (EC) (2012) EC Proposed Directive: Corporate Boards Quota: COM(2012) 614: http://ec.europa.eu/justice/gender-equality/files/womenonboards/directive_quotas_en.pdf[accessed 01.09.2017].

European Commission (EC) (2014) Commission Recommendation of 07.03.14 on Strengthening the Principle of Equal Pay between Men and Women through Transparency (2014/124/EU), Brussels: http://ec.europa.eu/justice/gender-equality/files/gender_pay_gap/c_2014_1405_en.pdf [accessed 26.07.2017].

European Commission (EC) (2015a) SHE Figures 2015, Directorate-General for Research and Innovation Directorate B - Open Innovation and Open Science Unit B.7 Science with and for Society, Brussels: European Commission, https://ec.europa.eu/research/swafs/pdf/pub_ gender_equality/she_figures_2015-final.pdf [accessed 24.07.2017].

European Commission (EC) (2015b) Horizon 2020 Work Programme 2014-15. 16. Science with and for Society, (Revised. E Decision C (2015) 2453 of 17 April 2015), http://ec.europa.eu/ research/participants/data/ref/h2020/wp/2014_2015/main/h2020-wp1415-swfs_en.pdf\#14 [accessed 24.07.2017].

European Commission (EC) (2015c) Reversing the Burden of Proof: Practical Dilemmas at the European and National Level, European Commission, Directorate-General for Justice and Consumers, http://ec.europa.eu/justice/newsroom/gender-equality/news/150417_en.htm [accessed 26.07.2017].

European Commission (EC) (2015d) Commission Staff Working Document Strategic engagement for gender equality 2016-19, SWD (2015) 278 final, http://ec.europa.eu/justice/gender-equality/ files/documents/151203_strategic_engagement_en.pdf [accessed 31.10.2017]

European Commission (EC) (2016a) Horizon 2020 Annual Monitoring Report 2015, http://ec. europa.eu/research/evaluations/pdf/archive/h2020_monitoring_reports/second_h2020_annual_ monitoring_report.pdf [accessed 24.07.2017].

European Commission (EC) (2016c) 'Launching a consultation on a European Pillar of Social Rights', http://europa.eu/rapid/press-release_IP-16-544_en.htm [accessed 24.07.2017].

European Commission (EC) (2017a) 'EC factsheet: delivering on the European Pillar of Social Rights - questions and answers', http://europa.eu/rapid/press-release_MEMO-17-1005_en.htm [accessed 24.07.2017].

European Commission (EC) (2017b) The European Pillar of Social Rights in 20 Principles', https://ec.europa.eu/commission/priorities/deeper-and-fairer-economic-and-monetary-union/ european-pillar-social-rights/european-pillar-social-rights-20-principles_en [accessed 24.07.2017]. 
European Commission (EC) (2017c) Mutual Learning Programme in Gender Equality, http://ec.europa.eu/justice/gender-equality/other-institutions/good-practices/index_en.htm [accessed 26.07.2017].

European Commission (EC) (2017d) 2017 Report on Equality between Women and Men in the $E U$, European Union. http://ec.europa.eu/newsroom/document.cfm?doc_id=43416 [accessed 01.09.2017].

European Institute for Gender Equality (EIGE) Gender Statistics Database, http://eige.europa. eu/gender-statistics/dgs/browse/wmidm [accessed 25.07.2017].

European Parliament Committee on Women's Rights and Gender Equality (2011) 'International Women's Day: call for quotas for women', press release 28 February 2011: http://www. womenlobby.org/IMG/pdf/ep_press_release_international_women_s_day_call_for_quota.pdf [accessed 28.09.2017].

EU (1993) Growth, Competitiveness, and Employment. The Challenges and Ways Forward into the 21st Century', COM (93) 700 final, Brussels: 05.12.1993, http://www.cvce.eu/obj/ commission_white_paper_on_growth_competitiveness_and_employment_1993-en-b0633a764cd7-497f-9da1-4db3dbbb56e8.html [accessed 24.07.2017].

EU (1995) Follow-up to the White Paper on Growth, Competitiveness and Employment Equal Opportunities for Women and Men, V/5538/95-EN, Report to the European Commission's Employment Task Force (DGV).

EU (1996) Incorporating Equal Opportunities for Women and Men into all Community Policies and Activities, COM(96) 67 final, http://eur-lex.europa.eu/legal-content/EN/TXT/PDF/?uri= CELEX:51996DC0067\&from=EN [accessed 01.09.2017].

EU (1999) Annual Report from the Commission Equal Opportunities for Women and Men in the European Union - 1998 - COM(1999) 106 final.

EU (2002) Employment in Europe, European Commission, Directorate-General for Employment and Social Affairs-Unit EMPL/A.1, ec.europa.eu/social/BlobServlet?docld=1894\&langld=en [accessed 25.07.2017].

EU (2003) Jobs, Jobs, Jobs - Creating more Employment in Europe, Report of the Employment Taskforce chaired by Wim Kok, https://publications.europa.eu/en/publicationdetail/-/publication/eba3e718-ec56-4da4-8b01-0c9101c8d4ac [accessed 01.09.2017].

EU (2013) Employment and Social Developments in Europe, http://ec.europa.eu/social/ keyDocuments.jsp?policyArea $=\&$ type $=0 \&$ country $=0 \& y e a r=0 \& a d v S e a r c h K e y=$ esdereport $\&$ mode $=$ advancedSubmit\&langld=en [accessed 01.09.2017].

EU (2014) 2014/124/EU: Commission Recommendation of 7 March 2014 on Strengthening the Principle of Equal Pay between Men and Women through Transparency, http://eur-lex. europa.eu/legal-content/EN/TXT/?uri=CELEX:32014H0124 [accessed 01.09.2017].

EUOBSERVER (2015) 'Commission withdraws maternity leave bill' https://euobserver.com/news/129416 [accessed 24.07.2017].

Fagan, C., Plantenga, J. and Rubery, R. (1995) 'Part-time work and inequality? Lessons from The Netherlands and the UK', in J. Lapeyre and R. Hoffman (eds.), A Time for Working - A Time for Living (Research papers commissioned for the ETUC/ETUI conference, Düsseldorf, December 1994), Brussels: European Trade Union Institute/ Labour Research Department.

Fagan, C., Rubery, R., Grimshaw, D., Smith, M., Hebson, G. and Figueiredo, H. (2005) 'Gender mainstreaming in the enlarged European Union: recent developments in the European employment strategy and social inclusion process', Industrial Relations Journal, 36, 6, 568-91.

Fagan, C., Grimshaw, D. and Rubery, R. (2006a) 'The subordination of the gender equality objective: the National Reform Programmes and 'making work pay' policies', Industrial Relations Journal, 37, 6, 571-92.

Fagan, C., Hegewisch, A. and Pillinger, J. (2006b) Out of Time - Why Britain Needs a New Approach to Working-Time Flexibility, London: Trades Union Congress, www.tuc.org.uk. 
Fagan, C., Gonzalez Menendez, M. and Gomez Anson, S. (eds.) (2012a) Women on Corporate Boards and in Top Management: European trends and policy, London: Palgrave Macmillan.

Fagan, C., Lyonette, C., Smith, M. and Saldaña-Tejeda, A. (2012b) The Influence of Working Time Arrangements on Work-Life Integration or 'Balance': A Review of the International Evidence, Background Report to the International Labour Office for the ILO Tripartite Meeting of Experts on Working time Arrangements, Geneva: International Labour Office, http://www.ilo.org/travail/whatwedo/publications/WCMS_187306/lang-en/index.htm [accessed 01.09.2017].

Fagan, C. and Norman, H. (2013) 'Men and gender equality: tackling gender segregation in family roles and in social care jobs', in F. Bettio, J. Plantenga and M. Smith (eds.), Gender and the European Labour Market, Oxon: Routledge, 199-223.

Fagan, C. and Vermeylen, G. (2016) 'Working time trends and work-life balance in Europe since the onset of the Great Recession', in S. Lewis, D. Anderson, C. Lyonette, N. Payne and S. Wood (eds.), Work-Life Balance in Times of Austerity and Beyond: Meeting the Needs of Employees, Organizations and Social Justice, London: Routledge.

Golden, L (2012) The Effects of Working Time on Productivity and Firm Performance: A Research Synthesis Paper, Background Report to the International Labour Office for the ILO Tripartite Meeting of Experts on Working time Arrangements, Geneva: International Labour Office, http://www.ilo.org/travail/whatwedo/publications/WCMS_187307/lang_en/index.htm [accessed 01.09.2017].

Hampton-Alexander Review (2016) Improving the Gender Balance on British Boards, http://thedaviesreview.com [accessed 01.09.2017].

Harding, C., Wheaton, B. and Butler, A. (2017) Childcare Costs Survey 2017, London: Family and Childcare Trust, https://www.familyandchildcaretrust.org/childcare-survey-2017 [accessed 01.09.2017].

Hastings, S. (2007) The Equal Pay Act: Its Impact on Collective Bargaining, Grading and Pay, http://www.unionhistory.info/equalpay/roaddisplay.php?irn=706 [accessed 01.09.2017].

House of Commons (2017) Children: Introduction of 30 Hours of Free Childcare in September 2017 (England) House of Commons Library Briefing paper no 7581, 12 July, www. parliament.uk/commons-library [accessed 01.09.2017].

Hyman, R. (2008) Britain and the European Social Model: Capitalism Against Capitalism?, Institute for Employment Studies IES Working Paper: WP19, http://www.employment-studies. co.uk/system/files/resources/files/wp19.pdf [accessed 01.09.2017].

Jenson, J. (2008) 'Writing women out, folding gender in. The European Union 'modernises' social policy', Social Politics: International Studies in Gender, State and Society, 15, 2, 1-23.

Jenson, J. (2009) 'Lost in translation: the social investment perspective and gender equality, Social Politics, $16,4,446-83$.

Karamessini, M. (2014) 'Structural crisis and adjustment in Greece: social regression and the challenge to gender equality', in M. Karamessini and J. Rubery (eds.), Women and Austerity: The Economic Crisis and the Future for Gender Equality, London: Routledge, 165-85.

Karamessini, M. and Rubery, J. (eds.) (2014) Women and Austerity: The Economic Crisis and the Future for Gender Equality, London: Routledge.

Labour Party (1996) New Labour New Life for Britain (election manifesto), http://www.politicsresources.net/area/uk/man/lab97.htm [accessed 28.09.2017].

Lewis, J. (2006) 'Work/family reconciliation, equal opportunities and social policies: the interpretation of policy trajectories at the EU level and the meaning of gender equality', Journal of European Public Policy, 13, 3, 420-37.

Lewis, S., Anderson, D., Lyonette, C., Payne, N. and Woods, S. (eds) (2016) Work-Life Balance in Times of Recession, Austerity and Beyond, London: Routledge.

Pillinger, J. (1992) Feminising the Market: Women's Pay and Employment in the European Community Basingstoke: Macmillan. 
Plantenga, J., Remery, C. and Rubery, J. (2007) 'Gender mainstreaming of employment policies: a comparative review of thirty European Countries,' EC, Directorate-General for Employment Social Affairs and Equal Opportunities, Unit G1. European Commission, https://www. research.manchester.ac.uk/.../gender-mainstreaming.../export.html [accessed 25.07.2017].

Pollack, M. and Hafner-Burton, E. (2000) 'Mainstreaming gender in the European Union', Journal of European Public Policy, 7, 3, Special Issue: 432-56.

Rubery, J. (2002) 'Gender mainstreaming and gender equality in the EU employment strategy', Industrial Relations Journal, 33, 5, 500-22.

Rubery, J. (2015) 'Austerity and the future for gender equality in Europe', International Labour Review, 68, $4,715-41$.

Rubery, J. and Grimshaw, D. (2015) 'The 40-year pursuit of equal pay: a case of constantly moving goalposts', Cambridge Journal of Economics, 39, 2, 319-43.

Rubery, J., Fagan, C., Grimshaw, D., Figueiredo, H. and Smith, M. (2001) 'Indicators on gender equality in the European employment strategy', Report of the Gender and Employment Expert Group (EGGE) for the Equal Opportunities Unit, Employment Directorate (DGV), Brussels: European Commission, 131 [Also available in French].

Rubery, J., Grimshaw, D., Fagan, C., Figueiredo, H. and Smith, M. (2003) 'Gender equality still on the European agenda - but for how long?' Industrial Relations Journal, 34, 5, 477-97.

Rubery, J., Figueiredo, H., Smith, M., Grimshaw, D. and Fagan, C. (2004) 'The ups and downs of European gender equality policy', Industrial Relations Journal, 35, 6, 603-28.

Rubery, J. and Kouliadaki, A. (2016) Closing the Gender Pay Gap. A Review of the Issues, Policy Mechanism and International Evidence, Geneva: ILO, http://www.ilo.org/wcmsp5/groups/public/— dgreports/—gender/documents/publication/wcms_540889.pdf [accessed 01.09.2017].

Smith, M. and Villa, P. (2010) 'The ever-declining role of gender equality in the European Employment Strategy', Industrial Relations Journal, 41, 6, 526-43.

Stratigaki, M. (2004) 'The co-optation of gender concepts in EU policies: the case of "reconciliation of work and family"', Social Politics, 11, 1, 30-56.

Tomlinson, J. (2007) 'Employment regulation, welfare and gender regimes: a comparative analysis of women's working-time patterns and work-life balance in the UK and the US', International Journal of Human Resource Management, 18, 3, 401-15.

Tucker, P. and Folkard, S. (2012) Working Time, Health and Safety: a Research Synthesis Paper, Background Report to the International Labour Office for the ILO Tripartite Meeting of Experts on Working time Arrangements, Geneva: International Labour Office.

UN (1995) Fourth World Conference of Women: Beijing Declaration and Platform for Action, http://un.org/womenwatch/daw/beijing/platform/ [accessed 25.07.2017].

Walby, S. (2003) The European Union and Gender Equality: Emergent Varieties of Gender Regime, paper presented to 'National Feminisms in a Transnational Arena' conference, University of Wisconsin at Madison http://www.leeds.ac.uk/sociology/people/swdocs/European\% 20Union\%20and\%20gender\%20equality.pdf [accessed 01.09.2017].

Wickham, J. (2005) The End of the European Social Model - Before It Began?, Dynamo Project thematic working paper, http://www.iaq.uni-due.de/aktuell/veroeff/2005/dynamo10.pdf [accessed 01.09.2017].

Women's Budget Group (2017) 'WBG publishes its full gender impact assessment of the Spring Budget 2017', https://wbg.org.uk/main-feature/wbg-publishes-full-gender-impact-assessment-spring-budget2017/ [accessed 01.09.2017]

Zeitlin, J., Pochet, P. with Magnusson, L. (eds.) (2005) The Open Method of Coordination in Action: The European Employment and Social Inclusion Strategies, Brussels: P.I.E.-Peter Lang. 